\title{
Volume Trafik IP-Based dengan Pemodelan Jam Sibuk
}

\author{
MARISA PREMITASARI \\ Institut Teknologi Nasional Bandung \\ Email : marisa@itenas.ac.id
}

\begin{abstract}
ABSTRAK
Jaringan telekomunikasi saat ini men-generate trafik data yang berbasis IP. Salah satunya adalah kampus ITENAS Bandung yang menyediakan akses untuk user berupa volume trafik. Data user yang terekam pada server dicapture setiap harinya dan didapatkan nilai volume trafik ketika user melakukan upload dan download data yang terukur berdasarkan durasi waktu pemakaian user. Data dibuat tabel pengukuran dengan menggunakan pemodelan jam sibuk dimana trafik mempunyai nilai paling tinggi. Ada tiga metoda pemodelan jam sibuk yang dijadikan acuan yaitu FDMH, ADPH dan TCBH.Ketiga metoda tersebut diukur selama waktu enam puluh menit dengan akurasi setiap limabelas menit yang didapat berdasarkan pengukuran twenty four hours selama enam hari. Pengukuran menghasilkan nilai FDMH traffic untuk download sebesar 73.92863 erlang dan upload sebesar 11.99713 erlang. ADPH download menghasilkan 130.7596 erlang dan ADPH upload sebesar 21.10694 erlang TCBH memberikan nilai 124.9155 erlang untuk download dan 19.74883667 erlang untuk upload. Hasil ini sesuai dengan perhitungan trafik jam sibuk bahwa aFDMH $\leq$ aTCBH $\leq$ aADPH dimana trafik tertinggi terletak pada pukul 08.42-09.42.
\end{abstract}

Kata kunci: Trafik Telekomunikasi, volume trafik, FDMH, ADPH, TCBH

\begin{abstract}
Nowadays telecommunication network generates IP-Based traffic. One of them, named as ITENAS and located in Bandung is available to provide services for user by accesing its traffic volume. The data has recorded by system in various parameter. It seperated into upload and download data based on each user account and their time duration. The data then sorted into tables by using busy hour modelling. Measurement is done by taking 6 days time which start from 7 AM to 11 AM where the peak of busy hour has been captured manually. Reseacher using three different busy hours methods which is FDMH, ADPH and TCBH. The result shown 73.92863 erlang for download traffic and 11.99713 erlang for upload traffic by using FDMH methods. Meanwhile, ADPH methods shown 130.7596 erlang for download result and 21.10694 erlang for upload result. The rest, which is TCBH resulted in 124.9155 erlang for download traffic and 19.74883667 erlang for upload traffic. These results is in accordance with busy hours traffic comparasion formulas where aFDMH $\leq a T C B H \leq a A D P H$ where highest traffic lies on Wednesday at 08.42-09.42 AM
\end{abstract}

Keywords: Telecommunication traffic, traffic volume, FDMH, $\mathrm{ADPH}, \mathrm{TCBH}$ 


\section{LATAR BELAKANG}

Tahun 1979 telepon selular pertama kalinya dioperasikan di Tokyo Jepang oleh NTT (Nippon Telephone and Telegraph) dan dua tahun kemudian di-launching di Benua Eropa. Itulah awal dari generasi seluler pertama atau $1 G$. Selanjutnya AMPS (Advanced Mobile Phone System) dari United States mengeluarkan seri NMT (Nordic Mobile Telephone) dan TACS (Total Access Communications System) pada tahun 1982 (Sharma,2013). Jaringan telekomunikasi pada generasi pertama hanya mengenal trafik voice (Gupta, Patil). Pada generasi kedua sekitar tahun 1990 teknologi SMS muncul seperti yang dikutip oleh Charu (Charu,2015) dan timnya, namun trafik voice tetap merupakan isu utama (Gupta, Patil) .Generasi ketiga di-launching pada tahun 2000 dimana jaringan telekomunikasi sudah bermigrasi ke packet switching yang membangkitkan trafik data dan pada era ini teknologi smart phone diperkenalkan (Vora,2015). Ketika era jaringan seluler beralih ke era 4G maka trafik telekomunikasi berubah menjadi trafik IP Based atau trafik berbasis protokol internet seperti yang disebutkan oleh Khan (Khan,2009) dan timnya bahwa $4 G$ berisi tentang sebuah integrasi, network global yang mampu menyediakan solusi Internet Protocol yang komprehensif dimana voice, data dan multimedia streaming dapat selalu diakses oleh pengguna. $4 G$ ini juga disebut sebagai era jaringan konvergen dimana voice, komunikasi data serta multimedia dilewatkan ke dalam satu kanal saja (Gupta, Patil). Ada banyak sekali jenis trafik yang dibangkitkan pada jaringan IP Based. Contohnya adalah trafik yang berbasis protocol internet seperti HTTP (Hyper Text Transfer Protocol) yang digunakan untuk mengakses world wide web. Kemudian trafik FTP atau kependekan dari File Transfer Protokol yang merupakan sebuah protokol untuk mengunduh dan mengunggah file di jaringan internal. Selain itu, ada juga trafik yang melihat jumlah user dan volume trafik untuk mengukur berapa kapasitas upload dan download user. Trafik dapat diolah dengan berbagai cara untuk keperluan forecasting. Metoda pengolahan data trafik bisa digunakan dengan memakai pendekatan distribusi matematis atau menggunakan metoda jam sibuk. Pada penelitian ini penulis akan melakukan capture terhadap jumlah user dan volume traffic, dimana volume traffic dinyatakan dengan kapasitas download dan upload user dalam satuan B (Byte), MB(Mega Byte) dan GB (Giga Byte). Data akan diolah menggunakan tiga metoda jam sibuk dimana $A D P H$ akan menghitung nilai tertinggi dari sebuah trafik, $F D M H$ mengambil jam sibuk yang ditetapkan sepihak oleh operator dan $T C B H$ merata-ratakan jeda waktu dari tiap-tiap trafik yang memiliki nilai tertinggi. Sebagai perbandingan, ada beberapa studi literatur yang digunakan. Penelitian yang dikerjakan oleh Wahyudi (Wahyudi,2013) dan timnya menghitung perbandingan trafik jam sibuk dengan metode $A D P H, T C B H, F D M H$ dan FDMP untuk jaringan CDMA $20001 x$ pada BTS Inner City dan BTS Outer City. Hasil membuktikan bahwa $a F D M H \leq a F D M P \leq a T C B H \leq a A D P H$ dimana FDMP adalah Fixed Daily Measurement Periods yang mengukur trafik berdasarkan perioda tertentu. Kinerja jaringan yang handal dan memenuhi Qos dibutuhkan untuk melayani pelanggan jaringan telekomunikasi. Sani (Sani,2017) dan tim melakukan penelitian yang bertujuan untuk melihat salah satu parameter Qos yaitu utilisasi atau intensitas trafik yang sesuai harapan menggunakan metode $A D P H, T C B H$ dan $F D M H$. Hasil yang diraih dari setiap metode menunjukan bahwa nilai ADPH $>$ TCBH $>$ FDMH. Penelitian yang dilakukan oleh Manggala (Manggala,2017) dan timnya menghasilkan puncak jam tersibuk ada di jam 10.30-11.30 di jaringan terpadu kampus UMY dengan 
menggunakan berbagai metoda diantaranya $F D M H, T C B H$ dan ADPH. Pada Penelitian ini, metoda $F D M H, A D P H$ dan $T C B H$ akan digunakan untuk mencari waktu jam tersibuk pada enam hari jam kerja kampus dari volume trafik pengguna akses internet di ITENAS. Volume trafik yang didapat berupa kapasitas download dan upload user akan diambil waktu pendudukan total selama empat jam dimana pada rentang tersebut terdapat waktu tersibuk dengan bantuan tools Microsoft excel. Hasil waktu tersibuk diperlihatkan dalam nilai intensitas trafik setiap metode, kemudian hasilnya dibandingkan dengan tahap verifikasi pada rancangan penelitian.

\section{METODOLOGI PENELITIAN}

Metodologi yang dirancang pada penelitian ini diilustrasikan pada Gambar 1 yang merupakan urutan proses menentukan model matematis yang sesuai dengan trafik telekomunikasi pada suatu sistem telekomunikasi.

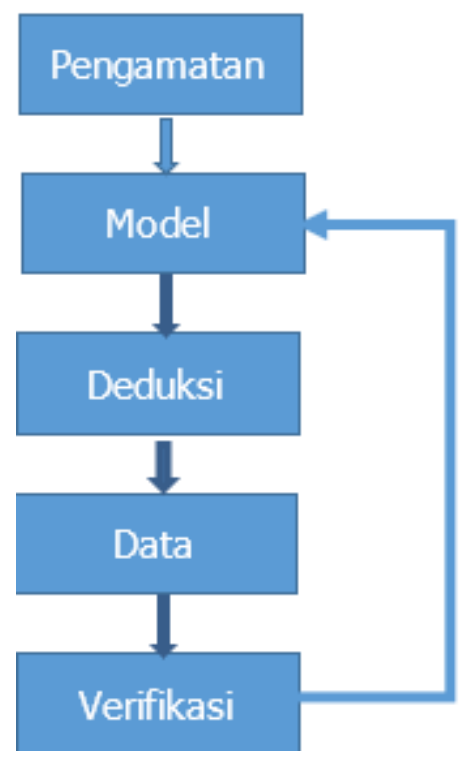

\section{Gambar 1. Model Trafik Telekomunikasi}

(Sumber: ITU-D SG 2/16 \& ITC,2001, hlm 15)

\subsection{Pengamatan}

Data trafik IP-based yang dibangkitkan pada jaringan server ITENAS, diamati dan di-capture selama satu minggu mulai dari tanggal 23 november 2017-30 November 2017. Data trafik yang diolah adalah volume trafik dari masing-masing user dimana nilai intensitas trafik dari jam sibuk akan dicari. Pada tahap ini, data trafik masih berupa data asli dan data diambil selama satu minggu mulai pkl 11.00 setiap harinya. Pengamatan dilihat melalui "software bawaan" untuk access point seri ubiquity yang terpasang pada server dimana data akan diambil secara manual. Pengamatan mengambil delapan hari mulai dari hari kamis sampai hari kamis berikutnya. 


\subsection{Model \& Dedukasi (Haryadi, 2012)}

Setelah melakukan pengambilan data, tahap selanjutnya adalah mencari model trafik yang relevan sesuai dengan tujuan dan data yang didapatkan melalui studi literatur. Pemilihan satu model matematis dilakukan pada tahap deduksi dimana dicari data yang paling mungkin mendekati sifat dan karakteristik trafik pada sistem telekomunikasi yang sedang dirancang atau yang sedang dianalisis (Haryadi, 2012). Karena tujuan penelitian ini adalah mencari waktu jam sibuk dan data yang didapatkan adalah trafik IP-Based untuk variasi trafik mingguan, maka pendekatan yang diambil adalah pendekatan dengan pemodelan jam sibuk. Pemodelan jam sibuk dipakai untuk variasi trafik mingguan dan diambil tiga pendekatan yaitu TCBH, FDMH dan ADPH.TCBH (Time Consistent Busy Hour) adalah waktu selama enam puluh menit (diukur dengan akurasi setiap lima belas menit) yang didapat berdasarkan pengukuran twenty four hours variations selama suatu perioda waktu yang panjang secara rata-rata terdapat trafik tertinggi. Persamaan (1) menunjukkan rumus perhitungan TCBH dimana $n$ adalah jumlah hari, $a$ adalah intensitas trafik perwaktu dan $\triangle$ merupakan waktu TCBH

$$
a_{T C B H}=\max _{\Delta} \frac{1}{N} \sum_{n=1}^{N} a_{n}(\Delta)
$$

Fixed Daily Measurement Hour atau disingkat FDMH adalah waktu selama enam puluh menit dan diukur dengan akurasi setiap lima belas menit yang ditentukan oleh suatu operator 4ystem telekomunikasi secara sepihak. Sama dengan $T C B H$, persamaan (2) untuk $T C B H$ ditentukan oleh $n$ yang merupakan jumlah hari, $a$ sebagai intensitas trafik perwaktu dan $\Delta$ sebagai waktu yang sudah ditentukan oleh operator

$$
a_{\text {FDMH }}=\frac{1}{N} \sum_{n=1}^{N} a_{n}\left(\Delta_{\text {fixed }}\right)
$$

Pendekatan terakhir adalah $A D P H$ atau kependekan dari Average Daily Peak Hour merupakan trafik selama enam puluh menit dengan akurasi setiap lima belas menit yang didapat berdasarkan pengukuran twenty four hours variation selama suatu perioda waktu yang panjang adalah secara rata-rata terdapat trafik tertinggi dimana persamaan (3) adalah rumus untuk $A D P H$

$$
a_{A D P H}=\frac{1}{N} \sum_{n=1}^{N} \max _{\Delta} a_{n}(\Delta)(3)
$$

\subsection{Data}

Data atau pengukuran data adalah bagaimana trafik akan diolah dan disimpulkan atau di-forecast. Trafik yang di-capture sebagai data asli disortir terlebih dahulu. Sortir data dilakukan dengan melihat parameter input pada metoda FDMH, $A D P H$ dan TCBH dimana data yang diambil yaitu upload, download dan durasi. Trafik data upload dan download akan diubah kesatuan MB (Mega 
Bytes). Selanjutnya durasi diubah ke dalam satuan interval waktu datangnya paket ke dalam perioda waktu jam sibuk. Perioda penentuan jam sibuk dimulai pkl 07.00-11.00 . Karena data diambil Pukul 11.00, maka jam tersebut menjadi acuan pengelompokan durasi pemakaian user ke dalam perioda waktu sehingga data berubah menjadi interval waktu kedatangan. Setelah data disortir kemudian data akan diolah berdasarkan rumus perhitungan ketiga metoda jam sibuk. Hal pertama yang dilakukan adalah mengubah tabel pengelompokan setiap lima belas menit menjadi tabel pengolahan baru untuk setiap rentang lima belas menit untuk dicari nilai trafik tertinggi dimana FDMH, mengambil nilai jam sibuk yang diasumsikan secara sepihak, $A D P H$ mengambil rata-rata trafik tertinggi setiap harinya dan TCBH mengambil perioda waktu dimana terdapat trafik tertinggi untuk dirata-ratakan dan dicari kembali nilai trafik tertinggi berdasarkan perioda rata-rata waktu tersebut. Nilai trafik diberikan dalam satuan erlang dimana erlang merupakan satuan tetap untuk intensitas trafik (Haryadi,2012). Pengolahan data dilakukan dengan mengubah data durasi user untuk upload dan download menjadi interval kedatangan diperioda waktu jam sibuk secara manual. Urutan proses pengolahan data dijelaskan pada diagram berikut (Gambar 2)

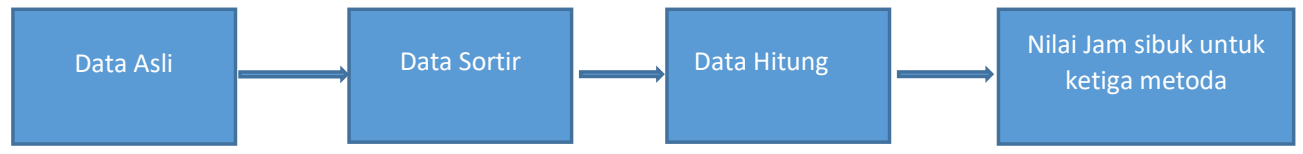

Gambar 2. Urutan Pengolahan Data

\section{Verifikasi}

Verifikasi data disini adalah perbandingan nilai dari data yang sudah diolah dengan ketiga metoda, dimana bila perhitungan datanya benar maka akan didapat $a F D M H \leq a T C B H \leq a A D P H$. Verifikasi selanjutnya dilakukan dengan mencari nilai intensitas trafik selama empat jam dimana nilai intensitas trafik pada sebuah kanal dari penyedia layanan adalah jumlah layanan sibuk pada suatu waktu yang diberikan atau diamati (Haryadi,2016). Intensitas trafik juga bisa disebut sebagai Volume Trafik (V) dibagi perioda pengamatan dibagi waktu pengamatan (T) ditulis pada persamaan (4), yang merupakan rumus intensitas trafik tanpa pemodelan (Hertiana, 2009)

$$
a=\frac{V}{T}(4)
$$

Tahap verifikasi dilakukan dua kali, pertama verifikasi terhadap perbandingan metoda, kedua verifikasi pemodelan jam sibuk dengan rumus intensitas trafik tanpa pemodelan

\section{ANALISIS DAN PEMBAHASAN}

Hasil pengamatan terlihat pada Tabel 1 yang merupakan hasil capture data trafik yang diambil setiap pukul 11.00 mulai dari tanggal 23 november 2017- 30 november 2017 dimana Tabel 1 menunjukkan contoh data yang di-capture secara 
random. Hasil capture di bawah berisi data nama gadget user, alamat IP (IP Address), nama jaringan wireless WLAN, nama access point beserta port (AP/Port), volume trafik (download \& upload) serta durasi koneksi (uptime).Parameter yang dijadikan observasi adalah volume trafik dan durasi. Volume trafik tersebut tersebar ke dalam satuan GB (Giga Bytes), MB (Mega Bytes) dan B (Bytes). Durasi user bervariasi untuk hari (d), jam (h), menit(m) dan detik (s).

Tabel 1. Data Asli Server ITENAS

\begin{tabular}{|c|c|c|c|c|c|c|}
\hline Name & $\begin{array}{l}\text { IP } \\
\text { Address }\end{array}$ & WLAN & $\begin{array}{l}\text { AP/P } \\
\text { ort }\end{array}$ & Down & Up & Uptime \\
\hline $\begin{array}{c}\text { android- } \\
\text { a8a8d41e3* } \\
* * 34 \mathrm{e} 5\end{array}$ & 172.16 .3 .38 & $\begin{array}{l}\text { HOTSPOT- } \\
\text { ITENAS }\end{array}$ & $\begin{array}{l}\text { APGd.2 } \\
0 \text { LT-1 }\end{array}$ & $314 \mathrm{MB}$ & 18.7 MB & $3 \mathrm{~h} 52 \mathrm{~m} 30 \mathrm{~s}$ \\
\hline $\begin{array}{l}\text { Sa**ung- } \\
\text { Galaxy-S7- } \\
\text { edge }\end{array}$ & 172.16 .2 .40 & $\begin{array}{l}\text { HOTSPOT- } \\
\text { ITENAS }\end{array}$ & $\begin{array}{c}\text { AP } \\
\text { Gd.01 } \\
\text { LT-3 }\end{array}$ & $580 \mathrm{~B}$ & $4.88 \mathrm{~KB}$ & $9 m 25 s$ \\
\hline $\begin{array}{l}\text { android- } \\
\text { 87c8b25f*** } \\
92 \mathrm{e} 53\end{array}$ & 172.16.0.199 & $\begin{array}{l}\text { HOTSPOT- } \\
\text { ITENAS }\end{array}$ & $\begin{array}{c}\text { AP } \\
\text { Gd.19B } \\
\text { LT-3 }\end{array}$ & $2.34 \mathrm{MB}$ & $581 \mathrm{~KB}$ & $1 \mathrm{~h} 8 \mathrm{~m} 47 \mathrm{~s}$ \\
\hline $\begin{array}{c}\text { Redmi3X- } \\
* * *\end{array}$ & 172.16 .3 .200 & $\begin{array}{l}\text { HOTSPOT- } \\
\text { ITENAS }\end{array}$ & $\begin{array}{l}\text { AP SC } \\
\text { LT-1 }\end{array}$ & $86.3 \mathrm{MB}$ & $5.61 \mathrm{MB}$ & $2 \mathrm{~h}$ \\
\hline $\begin{array}{c}\text { android- } \\
* * * 2908 \mathrm{~d} 43 \\
91 \mathrm{f} 5 \mathrm{~b} 8\end{array}$ & 172.16.7.127 & $\begin{array}{l}\text { HOTSPOT- } \\
\text { ITENAS }\end{array}$ & $\begin{array}{c}\text { AP } \\
\text { Gd.09 } \\
\text { LT-3 }\end{array}$ & $24.5 \mathrm{MB}$ & $2.33 \mathrm{MB}$ & $1 \mathrm{~h} 52 \mathrm{~m} 21 \mathrm{~s}$ \\
\hline $\begin{array}{c}\text { WIN10***I- } \\
1 \text { TB }\end{array}$ & 172.16 .1 .240 & $\begin{array}{l}\text { HOTSPOT- } \\
\text { ITENAS }\end{array}$ & $\begin{array}{c}\text { AP } \\
\text { Gd.18 } \\
\text { LT-1 }\end{array}$ & $440 \mathrm{~KB}$ & $352 \mathrm{~KB}$ & $50 \mathrm{~m} 21 \mathrm{~s}$ \\
\hline $\begin{array}{c}\text { android- } \\
14 c 08452 * * \\
* 38 \mathrm{~d} 3 \mathrm{a}\end{array}$ & $\begin{array}{c}172.16 .16 .23 \\
8\end{array}$ & $\begin{array}{l}\text { HOTSPOT- } \\
\text { ITENAS }\end{array}$ & $\begin{array}{c}\text { AP } \\
\text { Gd.08 } \\
\text { LT-2 }\end{array}$ & $5.79 \mathrm{MB}$ & $489 \mathrm{~KB}$ & $1 \mathrm{~m} 49 \mathrm{~s}$ \\
\hline $\mathrm{n}^{* *}$ & 172.16 .1 .70 & $\begin{array}{l}\text { HOTSPOT- } \\
\text { ITENAS }\end{array}$ & $\begin{array}{c}\text { AP } \\
\text { Gd.01 } \\
\text { LT-3 }\end{array}$ & $9.7 \mathrm{MB}$ & $850 \mathrm{~KB}$ & $2 \mathrm{~m} \mathrm{25s}$ \\
\hline$* * *$-iPad & 172.10 .1 .3 & $\begin{array}{l}\text { HOTSPOT- } \\
\text { ITENAS }\end{array}$ & $\begin{array}{c}\text { AP } \\
\text { Gd.20 } \\
\text { LT-1 }\end{array}$ & $O B$ & $0 \mathrm{~B}$ & $1 \mathrm{~m} \mathrm{52s}$ \\
\hline $\begin{array}{c}\text { android- } \\
8 \mathrm{e} 237 \mathrm{~b} 4 \mathrm{f} 516 \\
\mathrm{c} 6^{* * *}\end{array}$ & 172.16 .2 .0 & $\begin{array}{l}\text { HOTSPOT- } \\
\text { ITENAS }\end{array}$ & $\begin{array}{c}\text { AP } \\
\text { Gd.19B } \\
\text { LT-3 }\end{array}$ & $51.3 \mathrm{MB}$ & $6.69 \mathrm{MB}$ & $1 \mathrm{~h} 6 \mathrm{~m} 12 \mathrm{~s}$ \\
\hline
\end{tabular}

Data asli diolah menjadi data sortir seperti ditunjukkan oleh Tabel 2 (download) dan Tabel 3 (upload) dimana durasi (uptime) diubah ke dalam interval waktu kedatangan dengan mengambil empat jam lebih awal dari waktu dan data di-capture pada pukul 
11.00 siang. Durasi user yang dikategorikan trafik adalah durasi mulai dari detik (s) ke 0 sampai empat jam (h) sebelum pukul 11.00. Hari yang dihitung adalah Hari Kamis (hari 1), Hari Jum'at (hari 2), Hari Senin (hari 3), Hari Selasa (hari 4), Hari Rabu(hari 5) dan Hari Kamis (hari 6) dimana hari sabtu dan hari minggu tidak dihitung sebagai trafik. Trafik disortir untuk down (unduh) dan up (unggah) dengan perioda (p) jam sibuk $T C B H, F D M H$ dan $A D P H$. Parameter upload dan download diubah ke satuan $M B$.

Tabel 2. Hasil Sortir untuk Download

\begin{tabular}{|c|c|c|c|c|c|c|}
\hline $\mathbf{P}$ & Hari 1 & Hari 2 & Hari 3 & Hari 4 & Hari 5 & Hari 6 \\
\hline $07.00-07.15$ & 473.9 & 473.9 & 473.9 & 473.9 & 18.8182 & 145.5 \\
\hline $07.15-07.30$ & 10.2 & 10.2 & 10.2 & 10.2 & 3040.970 & 990.7 \\
\hline $07.30-07.45$ & 990.9 & 990.9 & 990.9 & 990.9 & 151.938 & 549.83 \\
\hline $07.45-08.00$ & 6.8346 & 6.8346 & 6.8346 & 6.8346 & 1766.295 & 422.2 \\
\hline $08.00-08.15$ & 2180.98 & 2180.9 & 2180.98 & 2180.98 & 2037.672 & 1197.77 \\
\hline $08.15-08.30$ & 677.37 & 677.37 & 677.37 & 677.37 & 889.124 & 999.68 \\
\hline $08.30-08.45$ & 2025.89 & 1348.5 & 1348.52 & 2025.89 & 1870.07 & 1393.8 \\
\hline $08.45-09.00$ & 1630.05 & 1630.0 & 1630.05 & 1630.05 & 1184.039 & 1915.96 \\
\hline $09.00-09.15$ & 1991.93 & 1991.9 & 1991.93 & 1991.9 & 1426.514 & 1954.53 \\
\hline $09.15-09.30$ & 2472.03 & 2472.0 & 2472.03 & 2472.03 & 2883.183 & 1339.99 \\
\hline $09.30-09.45$ & 1669.33 & 1669.3 & 1669.33 & 1669.33 & 2033.079 & 1178.84 \\
\hline $09.54-10.00$ & 850.684 & 1612.3 & 1612.32 & 1602.31 & 1615.187 & 2057.74 \\
\hline $10.00-10.15$ & 1750.76 & 1750.7 & 1429.53 & 428.522 & 2171.150 & 684.972 \\
\hline $10.15-10.30$ & 1237.26 & 1232.2 & 1069.65 & 2023.96 & 1446.781 & 1101.46 \\
\hline $10.30-10.45$ & 1313.98 & 1318.9 & 1313.98 & 1301.41 & 1034.669 & 1072.32 \\
\hline $10.45-11.00$ & 171.072 & 474.16 & 573.433 & 486.466 & 586.4135 & 640.285 \\
\hline
\end{tabular}

Tabel 3. Hasil Sortir untuk Upload

\begin{tabular}{|c|c|c|c|c|c|c|}
\hline $\mathbf{P}$ & Hari 1 & Hari 2 & Hari 3 & Hari 4 & Hari 5 & Hari 6 \\
\hline $07.00-07.15$ & 36.16 & 36.16 & 36.16 & 36.16 & 8.0706 & 17.22 \\
\hline $07.15-07.30$ & 2.4 & 2.4 & 2.4 & 2.4 & 173.804 & 86.72 \\
\hline $07.30-07.45$ & 64 & 64 & 64 & 64 & 27.0979 & 60.9 \\
\hline $07.45-08.00$ & 1.9265 & 1.9265 & 1.9265 & 1.9265 & 145.161 & 173.51 \\
\hline $08.00-08.15$ & 127.21 & 127.21 & 127.21 & 127.21 & 150.627 & 135.32 \\
\hline
\end{tabular}




\begin{tabular}{|c|c|c|c|c|c|c|}
\hline $08.15-08.30$ & 85.51 & 85.51 & 85.51 & 85.51 & 251.451 & 79.87 \\
\hline $08.30-08.45$ & 275.88 & 275.88 & 275.88 & 275.880 & 570.139 & 93.24 \\
\hline $08.45-09.00$ & 156.86 & 156.86 & 156.86 & 156.867 & 111.882 & 248.096 \\
\hline $09.00-09.15$ & 289.68 & 289.68 & 289.68 & 289.68 & 279.453 & 257.266 \\
\hline $09.15-09.30$ & 289.68 & 262.07 & 262.07 & 262.07 & 238.501 & 168.562 \\
\hline $09.30-09.45$ & 294.40 & 294.40 & 294.40 & 294.405 & 260.765 & 216.329 \\
\hline $09.45-10.00$ & 82.9576 & 592.6128 & 592.6128 & 590.3478 & 169.5001 & 248.4174 \\
\hline $10.00-10.15$ & 207.33 & 207.3304 & 157.8304 & 71.1682 & 241.9525 & 89.2606 \\
\hline $10.15-10.30$ & 296.224 & 295.4632 & 269.9142 & 209.08444 & 154.8943 & 486.8698 \\
\hline $10.30-10.45$ & 136.036 & 183.4741 & 136.0359 & 133.5285 & 510.5356 & 185.2306 \\
\hline $10.45-11.00$ & 14.4106 & 59.95343 & 73.04832 & 62.460832 & 68.69733 & 68.23304 \\
\hline
\end{tabular}

Karena ketiga metoda jam sibuk menggunakan parameter volume trafik jam sebagai nilai inputnya, maka pengolahan data selanjutnya adalah menjumlahkan volume trafik berdasarkan pembagian durasi jam sibuk untuk ketiga metoda tersebut. Data kemudian dijumlahkan dan dikelompokkan berdasarkan pembagian durasi jam sibuk yang diperlihatkan pada tabel berikut (tabel 4)

Tabel 4. Data Hitung untuk Download

\begin{tabular}{|c|c|c|c|c|c|c|}
\hline $\begin{array}{c}\text { Waktu } \\
\text { jam } \\
\text { sibuk }\end{array}$ & Hari 1 & Hari 2 & Hari 3 & Hari 4 & Hari 5 & Hari 6 \\
\hline $\begin{array}{c}07.00- \\
08.00\end{array}$ & 1481.8346 & 1481.8346 & 1481.835 & 1481.8346 & 1481.8346 & 1481.8346 \\
\hline $\begin{array}{c}07.15- \\
08.15\end{array}$ & 3188.9226 & 3188.9226 & 3188.923 & 3188.9226 & 3188.9226 & 3188.9226 \\
\hline $\begin{array}{c}07.30- \\
08.30\end{array}$ & 3856.0926 & 3856.0926 & 3856.093 & 3856.0926 & 3856.0926 & 3856.0926 \\
\hline $\begin{array}{c}07.45- \\
08.45\end{array}$ & 4891.0866 & 4213.7166 & 4213.717 & 4891.0866 & 4891.0866 & 4213.7166 \\
\hline $\begin{array}{c}08.00- \\
09.00\end{array}$ & 6514.309 & 5836.939 & 6514.309 & 6514.309 & 5980.906 & 5507.21 \\
\hline $\begin{array}{c}08.15- \\
09.15\end{array}$ & 6325.256 & 5647.886 & 6325.256 & 6325.256 & 5369.748 & 6263.975 \\
\hline $\begin{array}{c}08.30- \\
09.30\end{array}$ & 8119.923 & 7442.553 & 8119.923 & 8119.923 & 7363.808 & 6604.285 \\
\hline $\begin{array}{c}08.45- \\
09.45\end{array}$ & 7763.361 & 7763.361 & 7763.361 & 7763.361 & 7526.818 & 6389.334 \\
\hline
\end{tabular}


MIND Journal | ISSN (p): 2528-0015 | ISSN (e): 2528-0902

DOI : https://doi.org/10.26760/mindjournal
| Vol. 3 | No. 1 | Halaman 1 - 14

[Juni] [2018]

\begin{tabular}{|c|c|c|c|c|c|c|}
\hline $\begin{array}{c}09.00- \\
10.00\end{array}$ & 6983.989 & 7745.634 & 7735.623 & 7735.623 & 7957.966 & 6531.121 \\
\hline $\begin{array}{c}09.15- \\
09.30\end{array}$ & 6742.815 & 7504.46 & 6172.211 & 6172.211 & 8702.601 & 5261.559 \\
\hline $\begin{array}{c}09.30- \\
10.30\end{array}$ & 5508.046 & 6264.701 & 5724.141 & 5724.141 & 7266.199 & 5023.038 \\
\hline $\begin{array}{c}09.45- \\
10.45\end{array}$ & 5152.7 & 5914.345 & 5356.226 & 5356.226 & 6267.789 & 4916.51 \\
\hline $\begin{array}{c}10.00- \\
11.00\end{array}$ & 4473.087 & 4776.176 & 4240.373 & 4240.373 & 5239.015 & 3499.048 \\
\hline
\end{tabular}

Tabel 5 Data Hitung untuk Upload

\begin{tabular}{|c|c|c|c|c|c|c|}
\hline $\begin{array}{c}\text { Waktu } \\
\text { jam } \\
\text { sibuk }\end{array}$ & Hari 1 & Hari 2 & Hari 3 & Hari 4 & Hari 5 & Hari 6 \\
\hline $\begin{array}{c}07.00- \\
08.00\end{array}$ & 104.4865 & 104.4865 & 104.4865 & 104.4865 & 104.4865 & 104.4865 \\
\hline $\begin{array}{c}07.15- \\
08.15\end{array}$ & 195.5405 & 195.5405 & 195.5405 & 195.5405 & 195.5405 & 195.5405 \\
\hline $\begin{array}{c}07.30- \\
08.30\end{array}$ & 278.6505 & 278.6505 & 278.6505 & 278.6505 & 278.6505 & 278.6505 \\
\hline $\begin{array}{c}07.45- \\
08.45\end{array}$ & 490.5312 & 490.5312 & 490.5312 & 490.5312 & 490.5312 & 490.5312 \\
\hline $\begin{array}{c}08.00- \\
09.00\end{array}$ & 645.472 & 645.472 & 645.472 & 645.472 & 1084.1 & 556.526 \\
\hline $\begin{array}{c}08.15- \\
09.15\end{array}$ & 807.94 & 807.94 & 807.94 & 807.94 & 1212.926 & 678.472 \\
\hline $\begin{array}{c}08.30- \\
09.30\end{array}$ & 1012.112 & 984.5039 & 984.5039 & 984.5039 & 1199.976 & 767.164 \\
\hline $\begin{array}{c}08.45- \\
09.45\end{array}$ & 1030.637 & 1003.029 & 1003.029 & 1003.029 & 890.6026 & 890.2538 \\
\hline $\begin{array}{c}09.00- \\
10.00\end{array}$ & 956.7273 & 1438.774 & 1438.774 & 1436.509 & 948.2205 & 890.5752 \\
\hline $\begin{array}{c}09.15- \\
09.30\end{array}$ & 874.3757 & 1356.423 & 1306.923 & 1217.996 & 910.7192 & 722.5698 \\
\hline $\begin{array}{c}09.30- \\
10.30\end{array}$ & 880.9179 & 1389.812 & 1314.763 & 1165.006 & 827.1125 & 1040.878 \\
\hline $\begin{array}{c}09.45- \\
10.45\end{array}$ & 722.5481 & 1278.881 & 1156.393 & 1004.129 & 1076.883 & 1009.778 \\
\hline 0.965 & & & & \\
\hline
\end{tabular}




\begin{tabular}{|c|c|c|c|c|c|c|}
\hline $\begin{array}{c}10.00- \\
11.00\end{array}$ & 654.0011 & 746.2212 & 636.8289 & 476.242 & 976.0798 & 829.594 \\
\hline
\end{tabular}

Dari tabel diatas kita akan mengetahui trafik jam sibuk dengan masing masing metoda, yang pertama adalah $F D M H$, atau trafik yang jam sibuknya ditentukan oleh operator atau administrator jaringan atau pengamat trafik secara sepihak dimana jam sibuk untuk FDMH dijaringan ITENAS terdapat diantara pkl 10.00-11.00.

Tabel 6. Hasil Nilai Trafik FDMH

\begin{tabular}{|c|c|c|c|c|c|c|c|}
\hline $\begin{array}{c}\text { Trafik } \\
\text { FDMH }\end{array}$ & hari 1 & hari 2 & hari 3 & hari 4 & hari 5 & hari 6 & Average \\
\hline download & 4473.08711 & 4776.17619 & 4386.60774 & 4240.3732 & 5239.0152 & 3499.0483 & 4435.718 \\
\hline upload & 654.00112 & 746.221172 & 636.828864 & 476.24197 & 976.07979 & 829.59401 & 719.8278 \\
\hline
\end{tabular}

Untuk trafik $A D P H$, kita melihat dari peak trafik dari selang pembagian waktu jam sibuk sehingga didapat nilai sebagai berikut (Tabel 7)

Tabel 7. Hasil Nilai Trafik ADPH

\begin{tabular}{|c|c|c|c|c|c|c|c|}
\hline $\begin{array}{c}\text { Trafik } \\
\text { ADPH }\end{array}$ & hari 1 & hari 2 & hari 3 & hari 4 & hari 5 & hari 6 & Average \\
\hline download & 8119.92289 & 7763.36129 & 7763.36129 & 8119.9229 & 8702.6009 & 6604.285 & 7845.576 \\
\hline upload & 1030.63696 & 1438.7744 & 1438.7744 & 1436.5094 & 1212.926 & 1040.8776 & 1266.416 \\
\hline
\end{tabular}

Trafik yang terakhir mengkalkulasikan perhitungan selang pembagian waktu jam sibuk sehingga didapat TCBH Hour (menghitung selang waktu pada peak trafik) dan Trafik $T C B H$ (rata-rata dari selang waktu peak trafik untuk mendapatkan peak trafik yang baru dari metoda $T C B H$ ) sebagai berikut:

Tabel 8. TCBH Hour

\begin{tabular}{|c|c|c|c|c|c|c|c|}
\hline $\begin{array}{c}\text { TCBH } \\
\text { Hour }\end{array}$ & hari 1 & hari 2 & hari 3 & hari 4 & hari 5 & hari 6 & Average \\
\hline \multirow{2}{*}{ download } & \multirow{2}{*}{$08.30-09.30$} & $08.45-$ & $08.45-$ & $08.30-$ & $09.15-$ & $08.30-$ & $08.43-$ \\
& & 09.45 & 09.30 & 10.15 & 09.30 & 09.42 \\
\hline \multirow{2}{*}{ upload } & \multirow{2}{*}{$08.45-09.45$} & $09.00-$ & $09.00-$ & $09.00-$ & $08.15-$ & $08.30-$ & $08.43-$ \\
& 10.00 & 10.00 & 10.00 & 09.15 & 09.30 & 09.45 \\
\hline
\end{tabular}


Tabel 9. Nilai Trafik $T C B H$

\begin{tabular}{|c|c|c|c|c|c|c|c|}
\hline $\begin{array}{c}\text { Trafik } \\
\text { TCBH }\end{array}$ & hari 1 & hari 2 & hari 3 & hari 4 & hari 5 & hari 6 & Average \\
\hline download & 7763.36129 & 7763.36129 & 7763.36129 & 7763.3613 & 7526.8178 & 6389.3341 & 7845.576 \\
\hline upload & 956.7273 & 1438.7744 & 1438.7744 & 1436.5094 & 948.2205 & 890.5752 & 1184.93 \\
\hline
\end{tabular}

Finalisasi dari ketiga metoda tersebut adalah mendapatkan nilai trafik dalam satuan Eh(Erlang hours) sehingga setiap nilai rata-rata dari upload dan download dibagi dengan 60, kecuali $T C B H$ Hours karena nilai yang diambil adalah Trafik TCBH-nya

Tabel 10. Tabel Nilai Trafik Final

\begin{tabular}{|c|c|c|c|}
\hline Hasil Trafik & aFDMH & aADPH & aTCBH \\
\hline Download & $\begin{array}{c}73.92863 \\
\text { Eh }\end{array}$ & $\begin{array}{c}130.7596 \\
\text { Eh }\end{array}$ & 124.9155474 \\
\hline Upload & $\begin{array}{c}11.99713 \\
\text { Eh }\end{array}$ & $\begin{array}{c}21.10694 \\
\text { Eh }\end{array}$ & 19.74883667 \\
\hline
\end{tabular}

Hasil tabel 10 menyimpulkan bahwa aFDMH $\leq a T C B H \leq a A D P H$ untuk download $(73.92863 \leq 124.9155474 \leq 130.7596)$ dan upload $(11.99713 \leq 19.74883667 \leq 21.10694)$. Bila kita melihat nilai intensitas setiap metodanya, maka hari 5 (hari rabu) pukul 10.00-11.00 terdapat trafik tertinggi untuk metoda $F D M H$. Tabel 5 menjelaskan bahwa nilai trafik tertinggi dengan metoda $A D P H$ berada di hari 5 (hari rabu) untuk download serta hari 2 (jum'at) \& hari 3 (Senin)untuk upload. Sementara trafik dengan metoda TCBH menyimpulkan bahwa jam sibuk terjadi di hari 1 sampai hari 4 dimana upload tertinggi terjadi di hari 2 \& hari3. Bila kita membandingkan ketiga hasil metoda dengan nilai intensitas trafik untuk total waktu kependudukan per waktu pengamatan, maka kita mendapatkan nilai intensitas trafik (nilai tanpa pemodelan jam sibuk) perharinya yang diperlihatkan pada tabel 11 .

Tabel 11. Nilai Intensitas Trafik Tanpa Pemodelan Jam Sibuk

\begin{tabular}{|c|r|r|r|r|r|l|}
\hline Hari 1 & Hari 2 & Hari 3 & Hari 4 & Hari 5 & Hari 6 & Average \\
\hline 125.3577 & 121.825 & 121.1708 & 122.2332 & 144.2133 & 111.1329 & 124.3222 \\
\hline
\end{tabular}

Hasil pada nilai average, membuktikan bahwa nilai tersebut mendekati nilai untuk metoda TCBH download dimana $124.3222 \approx 124.9155474$. Sebagai tambahan, dibawah ini adalah tabel 10 dan 11 yang menunjukkan tabel hari sibuk volume trafik upload dan download yang dilakukan dengan pembobotan manual, dimana nilai trafik terendah diberi angka 1 dan nilai trafik tertinggi diberi angka 6 . Nilai pada tabel 12 ( Nilai trafik tanpa pemodelan ) dimasukkan sebagai pembanding bila ada hari dengan nilai trafik yang sama. 
Tabel 12. Hari sibuk untuk download

\begin{tabular}{|c|c|c|c|c|c|}
\hline Download & FDMH & ADPH & TCBH & $\begin{array}{c}\text { Tanpa } \\
\text { Pemodelan }\end{array}$ & $\begin{array}{c}\text { rata-rata } \\
\text { bobot }\end{array}$ \\
\hline $\begin{array}{c}\text { Hari } \\
\text { 1(Kamis) }\end{array}$ & $\mathbf{4}$ & $\mathbf{5}$ & $\mathbf{6}$ & $\mathbf{5}$ & $\mathbf{5}$ \\
\hline Hari 2 (Jum'at) & 5 & 3 & 3 & 3 & 3.5 \\
\hline Hari 3 (Senin) & 3 & 2 & 4 & 2 & 2.75 \\
\hline Hari 4 (Selasa) & 2 & 4 & 5 & 4 & 3.75 \\
\hline Hari 5(Rabu) & 6 & 6 & 2 & 6 & 5 \\
\hline Hari 6(Kamis) & 1 & 1 & 1 & 1 & 1 \\
\hline
\end{tabular}

Pada tabel 12 hari sibuk terletak di hari 1(kamis) dan hari 5 (Rabu) karena bobotnya bernilai paling tinggi yaitu 5 . Tabel 13 menunjukkan bobot tertinggi di hari jum'at untuk upload yaitu 5

Tabel 13. Hari Sibuk untuk Upload

\begin{tabular}{|c|c|c|c|c|c|}
\hline Upload & FDMH & ADPH & TCBH & $\begin{array}{c}\text { Tanpa } \\
\text { Pemodelan }\end{array}$ & $\begin{array}{c}\text { Rata-rata } \\
\text { bobot }\end{array}$ \\
\hline Hari 1 (Kamis) & 3 & 1 & 2 & 5 & 2.75 \\
\hline Hari 2 (Jum'at) & 5 & 6 & 6 & 3 & 5 \\
\hline Hari 3(Senin) & 2 & 5 & 5 & 2 & 3.5 \\
\hline Hari 4(Selasa) & 1 & 4 & 4 & 4 & 3.25 \\
\hline Hari 5(Rabu ) & 6 & 3 & 1 & 6 & 4 \\
\hline Hari 6 (Kamis) & 4 & 2 & 3 & 1 & 2.5 \\
\hline
\end{tabular}

Tabel 14 adalah tabel hasil hari sibuk rata-rata download dan upload dan didapat hari sibuk untuk sample enam hari terjadi di hari rabu (nilai bobot 4.5) 
Tabel 14. Hasil perhitungan Hari Sibuk

\begin{tabular}{|c|c|c|c|}
\hline Hari & Download & Upload & $\begin{array}{l}\text { Rata-rata } \\
\text { Bobot }\end{array}$ \\
\hline Hari 1 (Kamis) & 5 & 2.75 & 3.875 \\
\hline Hari 2 (Jum'at) & 3.5 & 5 & 4.25 \\
\hline Hari 3(Senin) & 2.75 & 3.5 & 3.125 \\
\hline Hari 4(Selasa) & 3.75 & 3.25 & 3.5 \\
\hline Hari 5(Rabu ) & 5 & 4 & 4.5 \\
\hline Hari 6 (Kamis) & 1 & 2.5 & 1.75 \\
\hline
\end{tabular}

\section{KESIMPULAN}

Trafik dijaringan $4 G$ sudah merupakan trafik IP-Based maka metoda dan pola trafik bermigrasi dari yang asalnya telephony ke data. Jaringan konvensional yang membangkitkan trafik telephony berubah menjadi jaringan yang berbasis packet switching dimana trafik seperti volume trafik untuk upload dan download user dibangkitkan. Pemodelan jam sibuk dengan metoda $F D M H$, ADPH dan TCBH merupakan kesatuan metoda yang tidak dapat dipisahkan. FDMH digunakan untuk mencari asumsi jam sibuk, sehingga perhitungan data bisa dilakukan pada jam tertentu saja. $A D P H$ digunakan untuk mencari nilai trafik tertinggi dimana nilainya akan jadi nilai input untuk mencari trafik dengan metoda $T C B H$ dimana metoda TCBH merupakan perhitungan final untuk mendapat nilai yang akurat. Trafik tertinggi tidak dapat disimpulkan dengan melihat peak trafiknya saja. Sebagai contoh adalah hari 1 pukul 08.30-09.30 pada download dimana nilai trafik sebelum dan sesudah peak trafik juga diperhitungkan. Hasil perhitungan ketiga metoda pada jaringan ITENAS selama sampling enam hari di bulan November 2017 menunjukkan bahwa $a F D M H \leq a T C B H \leq a A D P H$ untuk download $(73.92863 \leq 124.9155474 \leq 130.7596)$ Eh dan upload $(11.99713 \leq 19.74883667 \leq$ 21.10694) Eh. Hasil ini sesuai dengan verifikasi, berarti durasi akses user dapat dimodelkan dengan jam sibuk. Verifikasi kedua menunjukkan bahwa trafik sibuk pada hari rabu pukul 08.42-09.42 untuk waktu pengamatan empat jam dari pukul 07.0011.00. Hasil ini dapat diolah lebih lanjut dengan mengambil sampel yang lebih banyak contohnya pada siang hari. Selanjutnya perlu dikembangkan penelitian untuk variasi trafik selama satu bulan atau satu tahun dengan menggunakan metoda yang sama dan bisa juga mengambil metoda lain seperti pendekatan distribusi matematis. Metoda jam sibuk dapat dipakai untuk volume trafik yang terdiri dari dua atau lebih jenis data, namun bila hanya menggunakan satu jenis data saja dapat digunakan rumus nilai intensitas trafik pada persamaan (4). Penelitian ini merupakan sampling dari jaringan skala kecil yang bisa digunakan untuk skala jaringan yang lebih besar, yaitu jaringan pada provider dengan menggunakan metoda yang sama. Jumlah jam dan hari pengukuran tidak mempengaruhi waktu dan nilai trafik terhadap ketiga metoda jam sibuk. 
Pengembangan dari penelitian ini adalah perlu adanya software yang dapat melakukan capture data dalam satuan MBPS, untuk setiap perioda waktu $T C B H, A D P H$ dan $F D M H$ sehingga tidak perlu dilakukan perhitungan yang cukup panjang untuk mengubah durasi waktu menjadi interval waktu kedatangan paket. Adanya keterbatasan dalam pengambilan data menyebabkan peneliti tidak dapat menganalisis trafik pada siang hari, sehingga waktu perioda hanya diambil pada pagi hari, dimana administrator mengasumsikan trafik sibuk pada pukul 11.00 untuk download user dan upload user dimana kedua jenis data ini direpresentasikan secara terpisah.

\section{DAFTAR RUJUKAN}

[1] Haryadi, S. (2012). Telecommunication Traffic, Technical and Business Consideration. Bandung: Dago Press.

[2] Haryadi, S. (2016). Telecommunication Traffic Unit and Mathematical Model. Telecommunication Traffic Engineering-Chapter 2. Institut Teknologi Bandung.

[3] Sani, A., F, Sukiswo, S., Christyono, Y. (2017). Analisis Trafik Metode ADPH, TCBH dan FDMH pada jaringan Backbone DWDM PT. Telkom Jawa Tengah. Jurnal Transient. 6(4)

[4] Sharma, P. (2013). Evolution of Mobile Wireless Communication Networks-1G to $5 G$ as well as Future Prospective of Next Generation Communication Network. International Journal of Computer Science and Mobile Computing. (pp:47-53)

[5] Santhi, K., R., \& Kumaran, G., S. (2006). Migration to 4G: Mobile IP-Based Solution. Advanced Int'l Conference on Telecommunications and Int'I Conference on Internet and Web Applications and Service

[6] Khan, A., H., Qadeer, M., A., Ansari, J., A., Waheed.,S. (2009). $4 G$ as Next Generation Network. International Conference on Future Computer and Communication. (pp:334-338)

[7] Manggala, S., T., Chamim, A., N., N., Surahmat., I. (2017). Analisis Trafik Penggunaan Jaringan Wifi Di Lingkungan Kampus Terpadu UMY. CITEE. (pp:181-185)

[8] Gupta, P., H., \& Patil, P. (2009). 4G-A New Era in Wireless Telecommunication.

[9] Charu \& Gupta., R., Mr. (2015).A Comparative Study of Various Generations in Mobile Technology. International Journal of Engineering Trends and Technoogy(IJETT). 28(7):328-332

[10]Wayhudi, E., Pamungkas, W., Basuseno, A. (2013). Perbandingan Perhitungan Trafik Jam Sibuk CDMA 2000 1x pada BTS Inner City dan BTS Outer City dengan Mempergunakan Metode ADPH, TCBH, FDMH dan FDMP. Jurnal Infotel. 2(5):33-41 
MIND Journal | ISSN (p): 2528-0015 | ISSN (e): 2528-0902

DOI : https://doi.org/10.26760/mindjournal
| Vol. 3 | No. 1 | Halaman 1 - 14 [Juni] [2018] 